\title{
PENCATATAN NIKAH, TALAK DAN RUJUK MENURUT UNDANG-UNDANG NO. 1/1974 DAN PP. NO. 9/1975
}

\section{Yasin}

\begin{abstract}
Abstrak
Apabila ternyata dari hasil penelitian itu terdapat halangan perkawinan atau belum dipenuhi syarat-syarat yang diperlukan maka keadaan itu segera diberitahukan kepada calon mempelai atau kepada orang tua atau kepada wakilnya. Apabila pemberitahuan itu telah dipandang cukup dan memenuhi syarat-syarat yang diperlukan serta tidak terdapat halangan untuk kawin, maka pegawai pencatat membuat pengumuman tentang pemberitahuan kehendak melangsungkan perkawinan menurut formulir yang ditetapkan dan menempelnya di Kantor Pencatatan yang mudah dibaca oleh umum.
\end{abstract}

\section{A. PENDAHULUAN}

Untuk sahnya suatu perkawinan yang ditinjau dari sudut keperdataan belaka adalah bilamana perkawinan tersebut sudah dicatat/didaftarkan pada kantor catatan sipil.

Selama perkawinan itu belum terdaftar, perkawinan tersebut masih belum dianggap sah menurut ketentuan hokum sekalipun mereka sudah memenuhi prosedur dan tata cara menurut ketentuan agama. Sedangkan bilamana ditinjau sebagai suatu perbuatan keagamaan pencatatan perkawinan hanyalah sekedar memenuhi administrasi perkawinan saja yang tidak menentukan sah atau tidaknya suatu perkawinan. ${ }^{1}$

Baik di dalam Undang-Undang Nomor 22 Tahun 1946 jo. UU Nomor 32 Tahun 1954 (penjelasan pasal 1) maupun UU Nomor 1 Tahun 1974 pasal 2 mengharuskan pencatatan terhadap tiap perkawinan. Dalam pada itu di Negara Indonesia terdapat dua instansi/lembaga yang diberi tugas mencatat perkawinan menurut agama Islam yaitu

\footnotetext{
${ }^{1}$ Abdurrahman, Ridwan Syahrani, Masalah-masalah Hukum Perkawinan di Indonesia, (Bandung: Alumni, 1978), h. 11
} 
Kantor Urusan Agama (KUA) Kecamatan untuk NTR (Nikah, Talak dan Rujuk) dan di Kantor Catatan Sipil.

\section{B. PEMBAHASAN}

\section{Pencatatan Nikah, Talak dan Rujuk Menurut Undang-Undang NO. 1 Tahun 1974}

Untuk sahnya suatu perkawinan yang ditinjau dari sudut keperdataan belaka adalah bilamana perkawinan tersebut sudah dicatat/ didaftarkan pada kantor catatan sipil.

Selama perkawinan itu belum terdaftar, perkakawinan tersebut masih belum dianggap sah menurut ketentuan hukum sekalipun mereka sudah memenuhi prosedur dan tata cara menurut ketentuan agama. Sedangkan bilamana ditinjau sebagai suatu perbuatan keagamaan pencatatan perkawinan hanyalah sekedar memenuhi administrasi perkawinan saja yang tidak menentukan sah atau tidaknya suatu perkawinan. ${ }^{2}$

Baik di dalam Undang-Undang No. 22 tahun 1946 jo. Undang-Undang No. 32 tahun 1954 (penjelasan pasal 1) maupun undang-undang No 1 tahun 1974 pasal (2) mengharuskan pencatatan terhadap tiap perkawinan. Dalam pada itu di negara Indonesia terdapat dua instansi/lembaga yang diberi tugas mencatat perkawinan menurut Agama Islam, yaitu di Kantor Urusan Agama kecamatan untuk NTR (Nikah, Talak Rujuk) dan di kantor Catatan Sipil (bulgerlijk stand) untuk perkawinan bagi mereka yang tunduk pada :

1. Stb. 1933 No. 75 jo. Stb. 1936 No. 607 tentang peraturan Pencatatan Sipil untuk orang Indonesia (asli) kristen di Jawa, Madura, Minahasa dan Ambonia.

2. Stb. 1847 No. 32, Pencatatan Perkawinannya dilakukan menurut ketentuanketentuan Stb. 1849 No. 25 tentang Peraturan Pencatatan Sipil Eropa.

3. Stb. 1917 No. 129, Pencatatan perkawinan dilakukan menurut ketentuanketentuan Stb. 1917 No. 130 jo. Stb. 1919 No. 81 tentang Peraturan Pencatatan Sipil Tionghoa

\footnotetext{
2 Abdurrahman SH, dan Riduan Syahrani, SH., Masalah-Masalah Hukum Perkawinan di Indonesia, (Bandung: Alumni, 1978), h. 11.
} 
4. Stb 1904 No. 279 tentang daftar-daftar Pencatatan Sipil untuk Perkawinan Campuran. ${ }^{3}$

Bagi orang indonesia yang beragama Islam pencatatan perkawinannya dilakukan oleh P.3NTR atas ketentuan Undang-Undang No. 22 tahun 1946 tentang pencatatan nikah, Talak, Rujuk, sebagaimana kemudian dengan undang-undang No. 32 tahun 1954 (LN, 1954 Mo. 98) dinyatakan tidak berlaku untuk seluruh Indonesia. Menurut pasal 1 ayat (1) Undang-undang No. 22 tahun 1946 nikah yang dilakukan menurut agama Islam diawasi oleh pegawai pencatat nikah yang diangkat oleh menteri Agama atau oleh pegawai yang ditunjuk olehnya. ${ }^{4}$

Jadi disini fungsi pegawai pencatat hanyalah mengawasi pernikahan dan pernikahan tetap dilakukan sesuai dengan ketentuan Hukum Islam yang tidak mensyaratkan campur tangan seorang pejabat negara dalam penentuan sah atau tidaknya pernikahan. Pengawasan ini hanya dimaksudkan untuk menjaga agar supaya pernikahan itu betul-betul diselenggarakan menurut ketentuan hukum Islam, sehingga oleh karenanya pernikahan yang dilaksanakan diluar pengawasan dan pengetahuan pegawai pencatat nikah adalah tetap sah asalkan dilakukan sesuai dengan ketentuan hukum islam.

Sejak disahkannya undang-undang No. 1 tahun 1974, Departemen Agama RI dalam hal ini Direktorat Jenderal Bimbingan Masyarakat Islam telah mengambil peranan secara langsung dan aktif untuk melaksanakan undang-undang itu, yang melibatkan dua Direktorat yakni Direktorat Urusan Agama Islam dan Direktorat Pembinaan Badan Peradilan Agama Islam berdasarkan KMA Nomor 18 tahun 1975. Masalah pencatatan menjadi beban tugas Direktorat Urusan Agama Islam. Sesuai dengan undang-undang No. 22 tahun 1946 jo. Undang-undang No 32 tahun 1954 jo undang-undang No. 1 tahun 1974. Peraturan pemerintah No 9 tahun 1975 dan peraturan Menteri Agama No. 3 tahun 1975 maka Departemen Agama melaksanakan secara

\footnotetext{
${ }^{3}$ Ibid., h. 51.

${ }^{4}$ Ibid., h. 12.
} 
vertikal sampai dengan kantor Urusan Agama Kecamatan melaksanakan tugas-tugas sebagai pencatat perkawinan, atau pencatat nikah. ${ }^{5}$

Dalam undang-undang nomor 22 tahun 1946 dikenal dengan istilah pegawai pencatat nikah, talak, dan rujuk, yang lazim disingkat PPN. Untuk luar Jawa Madura dibantu oleh tokoh-tokoh agama di desa-desa yang dianggap mampu dan cakap, dan mereka bukan pegawai negeri, diangkat menjadi pembantu pegawai pencatat nikah, talak dan rujuk hal ini diatur dengan surat penetapan Menteri Agama No. 14 tahun 1955 sedang pembantu pegawai pencatat nikah, talak, dan rujuk yang disingkat menjadi P3NTR. ${ }^{6}$

Mengenai pencatatan nikah, talak, dan rujuk dalam undang-undang No 1 tahun 1974 diatur dalam pasal 2 yang terdiri dari 2 ayat; ayat 1 tentang sahnya perkawinan, sedangkan ayat 2 tentang pendaftarannya. Seolah-olah karena terpisah, syarat pendaftaran tidak diperlukan untuk sahnya nikah. Tetapi dari ketentuan pasal 10 PP No. 9 tahun 1975 dapatlah disimpulkan bahwa keduanya (syarat materiil dan syarat formil itu) dilakukan bersamaan, syarat kumulatif dan sumultan; pasal 2 undang-undang No. 1 tahun 1974 tersebut berbunyi:

(1) Perkawinan adalah sah, apabila dilakukan menurut hukum masing-masing agamanya dan kepercayaannya itu;

(2) Tiap-tiap perkawinan dicatat menurut peraturan perundang-undangan yang berlaku. $^{7}$

Maka pencatatan perkawinan bukanlah merupakan syarat yang menentukan sahnya perkawinan, karena segala perkawinan di Indonesia sudah dianggap sah bilamana hukum agama dan kepercayaannya sudah menyatakan sah.

Akan tetapi bila dilihat penjelasan umum dari undang-undang tersebut yang menyatakan bahwa suatu perkawinan adalah sah bilamana dilakukan menurut hukum

${ }^{5}$ Mohd. Idris Ramulyo, SH., Hukum Perkawinan Islam, (suatu Analisis dari Undang-Undang No 1 Tahun 1974 dan Kompilasi Hukum Islam), (Cet. II;Jakarta: Bani Askara, 1999), h. 179.

${ }^{6}$ Ibid.,

7 H. Zainal Abidin Abubakar, SH., Kumpulan Perundang-undangan Dalam Lingkungan Peradilan Agama, (Jakarta : Al-Hikmah, 1993), h. 123. 
masing-masing agamanya dan kepercayaannya itu; dan disamping itu tiap-tiap perkawinan harus dicatat menurut peraturan perundang-undangan yang berlaku, dapat menimbulkan kesan bahwa pencatatan perkawinan mempunyai peranan yang menentukan juga terhadap suatu perkawinan.

Tidak ada lagi perkawinan yang dilakukan hanya menurut hukum agama dan kepercayaannya itu saja atau hanya dilakukan pencatatannya saja tetapi tidak berlangsung menurut hukum agama dan kepercayaannya itu, mengingat undang-undang No.1 tahun 1974 menyatakan bahwa suatu perkawinan adalah sah bilamana dilakukan menurut masing-masing hukum agamanya dan kepercayaannya itu, dan disamping itu tiap-tiap perkawinan harus dicatat menurut peraturan perundang-undangan yang berlaku seperti tersebut diatas. Pasal 2 ayat (1) dan (2) itu merupakan satu kesatuan yang tidak dapat dipisahkan.

Dari pasal (2) UU No 1 tahun 1974 tersebut diatas, terdapat 2 pendapat tentang tafsiran pasal tersebut yaitu;

Pertama, Ada kecenderungan dari beberapa sarjana hukum yang ingin memisahkan penafsiran pasal 2 ayat (1) dengan pasal 2 ayat (2), bahwa perkawinan adalah sah apabila dilakukan menurut hukum masing-masing agama da kepercayaannya itu, sedangkan pendaftaran adalah syarat administrasi saja dilakukan atau tidak, tidak merupakan suatu cacat atau lebih tegas lagi tidak menyebabkan tidak sahnya perkawinan tersebut.

Kedua, di lain pihak ada pula kecenderungan para sarjana Hukum yang menafsirkan pasal 2 ayat (1) dan pasal 2 ayat (2) itu bukan saja dari sudut yuridis semata-mata yaitu sahnya perkawinan, tetapi juga dikaitkan secara sosiologis yang menurut mereka pasal 1 ayat (1) dan pasal 2 ayat (2) itu tidak dapat dipisahkan sedemikian rupa, tetapi dianggap merupakan rangkaian kesatuan bagaikan benang dengan kulindan jalin menjalin menjadi satu, apabila yang satu lepas maka yang lain berkurang kekuatannya bahkan mungkin hilang. ${ }^{8}$

\footnotetext{
${ }^{8}$ Mohd Idris Ramulyo, SH., op.cit., h.122.
} 
Perkawinan menurut tafsiran pertama sudah sah tanpa adanya pencatatan, karena pencatatan itu hanya bersifat administrasi saja dan administrasi memerlukan biaya dalam bentuk uang. Maka ada kecenderungan orang-orang Islam sekarang tidak perlu mendaftarkan atau mencatatkan perkawinannya ke kantor pejabat pencatat nikah atau kepada P3NTR.

Pendapat kedua ini disamping penafsiran hukum dan sosiologis dikaitkan pula dengan akibat hukum dari suatu perkawinan, karena tidaklah bernama perkawinan kalu tidak ada akibat hukumya.

Pasal 12 Undang-undang No. 1 tahun 1974 menyebutkan "tata cara" pelaksanaan perkawinan diatur dalam peraturan perundang-undangan tersendiri”, sedangkan penjelasan pasal ini tidak mengurangi ketentuan yang diatur dalam undang-undang No. 22 tahun 1946 jo. Undang-undang No. 32 tahun $1954 .^{9}$

Pasal 1 Undang-undang No. 22 tahun 1946 jo. Undang-undang No. 32 tahun 1954, ini esensialnya ialah pada ayat (1) dan (2):

(1) Nikah yang dilakukan menurut agama islam, selanjutnya disebut nikah, diawasi oleh pegawai pencatat nikah yang diangkat oleh Menteri Agama atau oleh pegawai yang ditunjuk olehnya. Talak dan rujuk yang dilakukan menurut agama islam, selanjutnya disebut talak dan tujuk, diberitahukan kepada pegawai pencatat nikah

(2) Yang berhak melakukan pengawasan atas nikah dan menerima pemberitahuan tentang talak dan rujuk, hanya pegawai yang diangkat oleh menteri agama atau oleh pegawai yang ditunjuk olehnya. Dalam penjelasannya dinyatakan bahwa, maksud pasal ini ialah agar nikah, talak dan rujuk menurut agama islam supaya dicatat agar mendapat kepastian hukum. ${ }^{10}$

\footnotetext{
${ }^{9}$ Ibid., h. 126 dan 145.

${ }^{10}$ Dirjen Bimas dan Urusan Haji., Himpunan Peraturan Perundang-Undangan Perkawinan, (Jakarta: dirjen Urusan Agama Islam, 1996/1997) h, 3 dan 9.
} 
Peraturan Menteri Agama No. 1 tahun 1955 tentang kewajiba-kewajiban pegawai pencatat nikah dalam melaksanakan undang-undang No. 22 tahun 1946 jo. Undangundang No. 32 tahun 1954 dan penetapan menteri agama No. 14 tahun 1955 (tentang penunjukan dan tugas P3NTR) merupakan peraturan-peraturan yang sangat hubungan dalam melaksanakan undang-undang No 1 tahun 1974 ini. Demikian juga peraturan menteri agama No 1 tahun 1952 dan No. 4 tahun 1952 tentang wali hakim baik di jawa maupun diluar jawa. Peraturan-peraturan islam yang disempurnakan dengan peraturan menteri agama No. 3 tahun $1975 .^{11}$

Dari uraian-uraian tersebut diatas, maka dapat dipahami bahwa undang-undang No. 22 tahun 1946 jo. Undang-undang No. 32 tahun 1954 merupakan peraturan yang berisi hukum formil, maka undang-undang No 1 tahun 1974 merupakan hukum mareiil, yang sebelumnya tidak dikenal bagi golongan Islam, karena bagi umat islam hanya berlaku hukum adat.

\section{Pencatatan Nikah, Talak, dan Rujuk Menurut PP No. 9 Tahun 1975}

Setelah mengalami proses selama lenih kurang 15 bulan semenjak diundnagkannya undang-undang No. 1 tahun 1974, maka pada tanggal 1 April 1975 telah dapat diundangkan peraturan pemerintah No. 9 tahun 1975 tentang pelaksanaan undang-undang No. 1 tahun 1974 tentang perkawinan (Lembaran Negara Republik Indonesia tahun 1975 No. 12; tambahan lembaran negara RI tahun 1975 No. 3050). ${ }^{12}$

Pencatatan perkawinan dalam pelaksanaanya diatur dengan PP No. 9 tahun 1975 dan peraturan menteri agama nomor 3 dan 4 tahun 1975 bab II pasal 2 ayat (1) PP No. 9 tahun 1975, pencatatan perkawinan dari mereka yang melangsungkannya menurut agama Islam dilakukan oleh pegawai pencatat, sebagaimana dimaksud dalam undangundang nomor 32 tahun 1954, tentang pencatatan Nikah, talak dan rujuk. ${ }^{13}$

11 H. Arso Sosroatmodjo, SH dan H.A Wasit Aulawi, MA, Hukum Perkawinan di Indonesia, (Jakarta : Bulan Bintang, 1975), h. 42.

12 Ibid., h. 48.

${ }^{13}$ Mohd. Idris Ramulyo, SH., Op. Cit., h. 180. 
Dalam undang-undang No. 1 tahun 1974 tak banyak dijumpai pasal-pasal yang berkenaan dengan 'pencatatan pernikahan', yang mungkin dapat dijadikan pedoman untuk pemecahan masalah ini, akan tetapi ada beberaa ketentuan dalam peraturan pemerintah No. 9 tahun 1975 yang merupakan ketentuan pelaksanaan dari undangundang tersebut kita jumpai beberapa pasal yang mengatur masalah ini.

Dalam pasal 2 PP No. 9 tahun1975 ditentukan:

1. Pencatatan perkawinan dari mereka yang melangsungkan perkawinannya menurut agama islam, dilakukan oleh pegawai pencatat sebagaimana dimaksud dalam undang-undang No. 32 tahun 1954 tentang pencatatan Nikah, Talak dan Rujuk.

2. Pencatatan perkawinan dari mereka yang melangsungkan perkawinannya menurut agamanya dan kepercayaannya itu selain agama islam, dilakukan oleh pegawai pencatatan perkawinan pada kantor catatan sipil sebagaimana dimaksud dalam berbagai perundang-undangan mengenai pencatatan perkawinan.

3. Dengan tidak mengurangi ketentuan-ketentuan yang khusus berlaku bagi tatacara pencatatan perkawinan berdasarkan berbagai peraturan yang berlaku, tatacara pencatatan perkawinan dilakukan sebagaimana ditentukan dalam pasal 3 sampai dengan pasal 9 peraturan pemerintah ini. ${ }^{14}$

Pasal-pasal yang ada dalam peraturan pemerintah ini kelihatannya tidak begitu banyak memberikan patokan mengenai apa sebenarnya fungsi pencatatan ini. Dari ketentuan pasal 10 ayat (3) PP No. 9 tahun 1975 yang menentukan bahwa dengan mengindahkan tatacara perkawinan menurut masing-masing agamanya dan kepercayaannya itu, perkawinan dilaksanakan dihadapan pegawai pencatatan dan dihadiri oleh dua orang saksi; maka dapat dikatakan bahwa pencatatan perkawinan ini adalah merupakan salah satu prasyarat untuk melangsungkan perkawinan

Dengan adanya PP No. 9 tahun 1975 ini, maka pencatatan perkawinan dilakukan oleh dua instansi, yakni;

\footnotetext{
${ }^{14}$ H. Zainal Abidin Abubakar, SH., Op. Cit., h.151.
} 
1. Pegawai pencatat nikah, talak dan rujuk, bagi mereka yang beragama islam sebagaimana diatur dalam undang-undang No. 22 tahun 1946 jo. Undang-undang No. 32 tahun 1954.

2. Kantor pencatatan sipil atau instansi/pejabat yang membantunya, bagi mereka yang bukan beragama Islam, sebagaimana diatuur dalam berbagai peraturan perundang-undangan catatan sipil. ${ }^{15}$

Sebagai tindak lanjut dari ketentuan mengenai ‘pencatatan perkawinan' ini telah dikeluarkan beberapa peraturan dan petunjuk antara lain:

1. Peraturan Menteri Agama No. 3 tahun 1975 tentang Kewajiban Pegawai Pencatat Nikah dan Tata Kerja Peradilan Agama dalam melaksanakan Peraturan Perundang-undangan Perkawinan bagi yang beragama Islam, yang kemudian dilaksanakan lebih lanjut dengan instruksi Direktur Jenderal Bimbingan Masyarakat Islam, 12 Agustus 1975 No. D/INST/117/75, tentang Petunjuk Pelaksanaan Peraturan Menteri Agama No. 3 Tahun 1975.

2. Keputusan menteri dalam negeri, tanggal 1 Oktober 1975, No. 221 tahun 1975, tentang pencatatan perkawinan dan perceraian pada kantor catatan sipil sehubungan dengan berlakunya undang-undang perkawinan dan peraturan pelaksanaannya. ${ }^{16}$

Sebagaimana diketahui bahwa pelaksanaan perkawinan itu didahului kegiatankegiatan, baik yang dilakukan oleh calon mempelai maupun oleh pegawai pencatat nikah.

Dalam KUH Perdata (BW) tentang acara yang mendahului perkawinan diatur dalam pasal 50-58, sedangkan tentang pelaksanaan perkawinan dalam pasal 71-78, pasal 50 BW menyatakan bahwa semua orang yang hendak kawin harus memberitahukan kehendaknya itu kepada pegawai pencatatan sipil di tempat tinggal salah satu dari kedua pihak. Pemberitahuan ini harus dilakukan, baik sendiri, maupun dengan surat-surat yang dengan cukup kepastian memperlihatkan kehendak kedua calon suami isteri, dan

\footnotetext{
${ }^{15}$ Abdurrahman SH, dan Riduan Syahrani, SH., Op. Cit., h.15.

${ }^{16}$ Ibid., h. 16.
} 
tentang pemberitahuan itu oleh pegawai catatan sipil harus dibuat sebuah akte (pasal $51)^{17}$

Dalam pelaksanaan perkawinan khusunya tentang pemberitahuan perkawinan tidak diatur dalam undang-undang No. 1 tahun 1974 melainkan hanya terdapat di dalam PP No. 9 tahun 1975. Calon mempelai atau orang tuanya atau wakilnya memberitahukan kehendak melangsungkan perkawinan kepada pegawai pencatatan perkawinan (pasal 3 dan 4 PP No. 9/1975). Selanjutnya pegawai tersebut meneliti apakah syarat-syarat perkawinan telah dipenuhi, dan apakah tidak terdapat halangan menurut undang-undnag. Demikian pula meneliti surat-surat yang diperlukan (pasal 5 dan 6 PP No. 9/1975)

Apabila ternyata dari hasil penelitian itu terdapat halangan perkawinan atau belum dipenuhi syarat-syarat yang diperlukan maka keadaan itu segera diberitahukan kepada calon mempelai atau kepada orang tua atau kepada wakilnya (pasal 7 ayat (2) PP No 9.1975). Bila pemberitahuan itu telah dipandang cukup dan memenuhi syarat-syarat yang diperlukan serta tidak terdapat halangan untuk kawin, maka pegawai pencatat membuat pengumuman tentang pemberitahuan kehendak melangsungkan perkawinan, menurut formulir yang ditetapkan, dan menempelnya di Kantor Pencatatan yang mudah dibaca oleh umum. Pengumuman serupa itu juga dilakukan di Kantor Pencatatan yang daerah hukumnya meliputi tempat kediaman masing-masing calon mempelai (pasal 8 dan penjelasan pasal 9 PP No.9/1975). ${ }^{18}$

Untuk selanjutnya tugas PPN dan P3NTR sebagaimana diatur dalam peraturan Menteri Agama Nomor 3 tahun 1975, bab II pasal 6 tentang pemberitahuan kehendak nikah sampai bab IX pasal 22 tentang pembatalan pernikahan.

Bab III pasal 7 PMA No. 3 tahun 1975 dijelaskan bahwa pegawai pencatat Nikah (PPN) atau P3NTR yang menerima pemberitahua kehedak nikah memeriksa calon suami, isteri dan wali nikah, tentang ada atau tidaknya halangan pernikahan itu

\footnotetext{
${ }^{17}$ Prof Hilman Hadikusuma, SH., Hukum Perkawinan Indonesia, Menurut Perundangan Hukum Adat, Hukum Agama, (Bandung: Mandar Maju, 1990), h. 87.

${ }^{18}$ Ibid., h. 183.
} 
dilangsungkan baik halangan karena melanggar hukum munakahat atau karena melanggar peraturan perundang-undangan tentang perkawinan. ${ }^{19}$

Jadi pasal ini mempunyai dua aspek pelanggaran:

1. Terhadap hukum agama;

2. Terhadap peraturan perundang-undangan tentang perkawinan.

Oleh karena itu, apabila PPN atau P3NTR menerima pemberitahuan kehendak nikah, segera memeriksa dengan teliti calon suami, calon isteri dan wali nikah. Apabila ternyata memenuhi syarat-syarat dan rukun nikah atau hukum munakahat, pemberitahuan tersebut dapat diterima dan sebaliknya, apabila ternyata tidak memenuhi syarat maka dapat diadakan pencegahan sebagaimana diatur oleh Peraturan Menteri Agama Nomor 3 tahun 1975.

\section{PENUTUP}

Apabila ternyata dari hasil penelitian itu terdapat halangan perkawinan atau belum

dipenuhi syarat-syarat yang diperlukan maka keadaan itu segera diberitahukan kepada calon mempelai atau kepada orang tua atau kepada wakilnya. Apabila pemberitahuan itu telah dipandang cukup dan memenuhi syarat-syarat yang diperlukan serta tidak terdapat halangan untuk kawin, maka pegawai pencatat membuat pengumuman tentang pemberitahuan kehendak melangsungkan perkawinan menurut formulir yang ditetapkan dan menempelnya di Kantor Pencatatan yang mudah dibaca oleh umum. Pengumuman serupa itu juga dilakukan di Kantor Pencatatan yang daerah hukumnya meliputi tempat kediaman masing-masing calon mempelai.

\section{DAFTAR PUSTAKA}

${ }^{19}$ Ibid., h. 183 
Abdurrahman, dan Syahrani Riduan, Masalah-Masalah Hukum Perkawinan di Indonesia, Bandung: Alumni, 1978.

Ramulyo Mohd. Idris, Hukum Perkawinan Islam: Suatu Analisis dari Undang-Undang No 1 Tahun 1974 dan Kompilasi Hukum Islam, Jakarta: Bani Askara, 1999.

Abubakar Zainal Abidin, Kumpulan Perundang-undangan Dalam Lingkungan Peradilan Agama, Jakarta: Al-Hikmah, 1993.

Dirjen Bimas dan Urusan Haji., Himpunan Peraturan Perundang-Undangan Perkawinan, Jakarta: dirjen Urusan Agama Islam, 1996/1997.

Sosroatmodjo Arso dan H.A Wasit Aulawi, Hukum Perkawinan di Indonesia, Jakarta: Bulan Bintang, 1975.

Hadikusuma Hilman, Hukum Perkawinan Indonesia, Menurut Perundangan Hukum Adat, Hukum Agama, Bandung: Mandar Maju, 1990. 